\title{
Comentario tras la inmersión en El lugar del testigo. Escritura y memoria (Uruguay, Chile, Argentina)
}

Laura Strejilevich (2019). Santiago de Chile, Lom Ediciones, 320 pp.

\section{Alejandra Oberti}

Facultad de Ciencias Sociales, UBA

FSOC (Carrera de Sociología e IEALC) y FFyL (IIEGE) Este libro es un trabajo de largo de aliento llevado a cabo por una escritora que trabaja de manera sutil y amorosa con el lenguaje, produciendo una escritura conmovedora, y de una analista, una crítica aguda y nada concesiva. Inicié mi lectura sin conocer más que el título y empecé a leer de a poco hasta que quedé capturada de manera irreparable. Es imposible terminarlo en pocos días y llegar a comprender de qué trata leyendo en dosis homeopáticas. Mejor sumergirse, ir hasta el fondo para salir a flote de la mano de la propia Nora que se ocupa también de rescatar a la lectora.

Este ensayo es, por lo menos, tres libros a la vez:

- Es una discusión sobre el testimonio como género, sobre su lugar en la denuncia de los crímenes de Estado, sobre el problema de la verdad, sobre la influencia que la experiencia de la Shoa ejerce en relación al relato de los sobrevivientes de centros clandestinos. Es también un debate sobre el testimonio en América Latina, sobre su carácter literario y su fuerza política.

- Es un estado de cuestión y un análisis pormenorizado de la literatura testimonial referida a las dictaduras/ genocidos/terrorismos de Estado en Uruguay, Chile y la Argentina.

- Es un testimonio en sí mismo.

En efecto, si en la bibliografía de Nora Strejilevich encontramos textos como el artículo sobre literatura testimonial de mujeres en América Latina que escribió para The Cambridge History of Latin American Women's Literature, editado por lleana Rodríguez y Mónica Szurmuk y otros de carácter muy diferente, narrativo, como Una sola muerte numerosa, en este libro se juntan esos dos tipos de escritura por los cuales transita habitualmente, haciendo de El lugar del testigo un espacio donde se cruzan la crítica, la reflexión conceptual y la literatura testimonial a la vez analizada y expresada a partir de su propio testimonio, que atestigua su experiencia y la experiencia de otros/as.

En relación al primer "libro", le interesa el recorrido por algunas de las principales discusiones acerca del testimonio y el testigo (Agamben y su lectura del testimonio de Primo Levi, Beatriz Sarlo, el canon testimonial de América Latina, el testimonio como asunto de la literatura) porque:

El testigo cuenta -en el doble sentido de relatar y de importarle a otro- porque su versión revela el núcleo duro del experimento que pone en cuestión el estatuto de lo humano.

El testigo cuenta porque su memoria res-guarda escenas que revelan cómo el poder puede invadir y ocupar al sujeto y a la comunidad.

El testigo cuenta cómo se sostiene la insospechada capacidad para la resistencia en las situaciones límite $y$ tras ellas.

El testigo cuenta cómo vivían los hoy llamados desaparecidos, el modo en que habitaban ese sitio inhabitable donde transcurrió su último tramo existencial.

El testigo que cuenta nos revela mujeres y hombres resilientes y frágiles que, al darle cuerpo a su experiencia, reformulan las secuelas del horror y dejan de ser sus víctimas. Al contarlo con su tono y modulaciones, el testigo decide el cómo. Cada opción tiene sus límites y sus riesgos, ninguna es satisfactoria. (Strejilevich, 2019: 23) 
Por todas esas razones, Nora Strejilevich tiene mucho para decir en defensa del testimonio que entiende no como copia de una realidad sino como la construcción de una realidad que brinda la posibilidad de rearmar una subjetividad resistente. No solo un relato de los padecimientos, también una búsqueda de desarmar lo que el poder quiso hacer y un intento de recrear un mundo habitable.

Este libro es además un proyecto de poner en vínculo la literatura testimonial de Uruguay, Chile y la Argentina, analizando los modos en que en cada uno de esos países se ha narrado el horror. En este punto el trabajo de Nora es ambicioso no solo por la extensión geográfica, temporal, por la cantidad de obras que pone en juego o por el conocimiento de otras obras críticas. Se trata de más que eso, porque estamos ante un recorrido crítico por la literatura testimonial del cono sur de América Latina donde el testimonio sirve para delimitar el estado de situación de las identidades naciones y las realidades sociales en distintos momentos y geografías. El testimonio del horror, la narración de quienes han sobrevivido a la represión política en sus facetas más atroces son un instrumento que sirve para indicar los límites de la política de derechos humanos (o tal vez de derechos o más todavía la política a secas) de nuestra historia subcontinental. Así, ese artefacto más general que podríamos llamar el "testimonio de América Latina" sirve para leer cómo funciona la relación con el pasado, su presencia en la contemporaneidad y el grado de hipoteca que le deja al futuro. El testimonio así se erige en muestra de lo permitido, lo prohibido, lo silenciado, lo central y lo marginal de las historias nacionales.

No sabría decir si la literatura testimonial del cono sur constituye una serie, ni siquiera si en cada país hay una serie. Pero considero que El lugar del testigo muestra los vínculos más o menos explícitos que los unen. Los muestra como eslabones de una cadena, aunque (y tomo prestada la expresión de Josefina Ludmer) se trate de una cadena llena de torsiones.

Uruguay y el particular modo de tramitar el pasado de la izquierda, que entiende que de la derrota solo se puede salir hacia adelante, como si hacerse cargo del pasado no fuera también una forma de lidiar con el presente, da como resultado una literatura testimonial que se ocupa de lo que niega la historia oficial y que muestra cómo los sucesos desbordan cualquier intento de comprensión, pero que se mantiene firme en su intento de "dejar la muerte atrás" (133).

Los testimonios de Chile se ven siempre amenazados por la impunidad que se expresa también en el triunfo cotidiano de las políticas neoliberales que hacen de la sociedad chilena un ejemplo tercermundista de la razón de mercado, exigiendo reconciliación para arriesgar la frágil estabilidad del "retorno de la democracia”. Esa situación, paradójicamente, produce una literatura abundante que narra buscando reparar continuidades y otra que produce rupturas formarles mediante la ironía y la parodia.

La Argentina y su larga tradición de autoritarismos, masacres y golpes de Estado, donde la presencia de los organismos de derechos humanos se propone, junto con la demanda, innumerables tareas (querellar, investigar, identificar, nombrar, marcar) y la justicia como forma de narración.

En cada uno de estos países la cadena sufre torsiones, entradas violentas del contexto político, que la ponen en contacto con cierto exterior, cierta "realidad". Los textos muestran entonces aquello que Nora ya señaló conceptualmente al comienzo del libro: no hay una forma específica para narrar el testimonio de los campos. Hay diferentes estrategias que dependen de decisiones, gustos, capacidades, pero también de contextos de posibilidad, políticos y de recepción, todos potentes a su manera.

Ninguna historia contada, ningún modo de contarlo es invalidado en este libro. Solo hay una demanda de hacerse cargo de las consecuencias de los relatos y de la responsabilidad con quienes han tenido sus vidas arrasadas.

Y en relación a esto hay una intervención que quiero rescatar porque me parece especialmente cuidadosa y es cuando se refiere a la violencia sexual y la reducción a servidumbre que padecieron las mujeres detenidas-desaparecidas y la acusación de traición que sufrieron muchas. El fin de la historia de Liliana Heker y Recuerdo de la muerte de Miguel Bonasso son algunos de los ejemplos en este punto. Nora los lee preguntándose el porqué de esas opciones narrativas, por qué justamente en relación a este punto los relatos se tornan lineales y poco comprensivos, por qué no se busca contar las encrucijadas en las que se encontraron las sobrevivientes con un lenguaje que dé cuenta de la complejidad.

Finalmente, en relación al tercer libro que es este libro, El lugar del testigo es también en sí mismo testimonio y aquí encontramos la última torsión. Justamente en el apartado dedicado a la literatura testimonial en la Argentina, Nora se refiere a si misma en primera persona y en tercera persona alternativamente. Pero al cerrar el capítulo, y a la vez el libro, su testimonio 
se hace presente en un doble juego de testimonio y de crítica. Nos vuelve a traer ese texto preciosista Una sola muerte numerosa, en el cual cose (o borda) con la voz propia y la de otros y otras un relato en muchos tiempos. Mi testimonio, dice Nora, "no es mi propio testimonio sino, ante todo, un conjunto de voces entramadas con la mía" (278). Un conjunto de voces recogidas por ella misma y que se dan cita amorosamente en un texto que no trae solamente la historia del terror estatal sino también la historia familiar y la vida que hubiera podido ser.

Vemos entonces que el testimonio reconstruye no solo los acontecimientos, sino algo más, lo que hubiera podido ser y también cómo nos vemos en esa vida.

Quiero terminar con una cuestión que me desvela desde hace años. Qué hacemos con estos relatos, cómo los tratamos en su fragilidad pero también en su fortaleza. Cómo nos hacernos cargo de que muchas veces el problema está en la escucha, de que los testimonios necesitan ser acogidos (como ejemplifica el caso de los testimonios de la violencia sexual). El último párrafo de El lugar del testigo me parece que aporta una pista fundamental en ese sentido:

Mientras participaba en los juicios por crímenes de lesa humanidad sin dejar de cuestionar dicho estatuto, percibí la falta de hospitalidad hacia los sobrevivientes fuera de las redes solidarias y del rito judicial. Por eso quise abogar por escritos que la crítica no termina de aceptar, en los que vibra la materialidad de la experiencia límite; escritos con resonancia lírica, crítica y existencial. Así nace El lugar del testigo. Escritura y memoria (Uruguay, Chile y Argentina) (2019).

Así nace este libro, como un espacio de hospitalidad, sin duda. 
